\title{
Check-list of the Tachinidae (Diptera) of Mato Grosso do Sul, Brazil
}

\author{
Silvio Shigueo Nihei', André César Lopes ${ }^{1,2}$, \\ Rodrigo de Vilhena Perez Dios ${ }^{\top} \&$ Filipe Macedo Gudin’
}

1. Departamento de Zoologia, Instituto de Biociências, Universidade de São Paulo, São Paulo, Brazil. (silvionihei@gmail.com)
2. Departamento de Zoologia, Setor de Ciências Biológicas, Universidade Federal do Paraná, Curitiba, Brazil.

Received 21 November 2016

Accepted 6 February 2017

DOI: 10.1590/1678-4766e2017141

ABSTRACT. In the state of Mato Grosso do Sul, which is composed by four macroregions, Cerrado, Chaco, Atlantic Forest and Pantanal, there are 39 species and 24 genera of Tachinidae based on the literature. The subfamily Tachininae, with 15 species occurring in the State, has the highest representativeness, while the other subfamilies, Exoristinae, Phasiinae, and Dexiinae, with respectively 14, 7 and 3 species.

KEYWORDS. Brazil, diversity, Neotropical region, Biota-MS Program.

RESUMO. Check-list de Tachinidae (Diptera) do estado de Mato Grosso do Sul, Brasil. No estado do Mato Grosso do Sul, que é composto por quatro macrorregiões, Cerrado, Chaco, Mata Atlântica e Pantanal, foram encontrados 39 espécies e 24 gêneros de Tachinidae, baseado na literatura. A subfamília Tachininae, com 15 espécies ocorrendo no estado, teve maior representatividade, enquanto as outras subfamílias, Exoristinae, Phasiinae e Dexiinae, obtiveram respectivamente 14,7 e 3 espécies.

PALAVRAS-CHAVE. Brasil, diversidade, região Neotropical, Programa Biota-MS.

Tachinidae is one of the largest families of Diptera, with about 10,000 species worldwide distributed, inhabiting all regions except for Antarctic (StiREMAN et al., 2006). The Neotropical region presents the highest diversity with 2,864 species (GUIMARÃES, 1971). This number is certainly downestimated and after 40 years the number of species should be over the order of 3,000. In Brazil, about 720 species has been considered (CARVALHO et al., 2012, following GUIMARÃES, 1971). The actual size of the family is probably much larger because some regions (Neotropical, Afrotropical, Oriental and Australasian) contain a large number of undescribed species (O'HARA, 2011). Add to that the out-of-date catalogues and the reduced number of experts in those regions and we could get much higher numbers into the actual account.

The family exhibits a huge diversity of morphological patterns, although there is a characteristic shared by all its species (whose larval development are known), the endoparasitoid habit on arthropods, mainly insects (STIREMAN, 2006; Wood \& ZumBADo, 2010). As parasitoids, they have great importance regulating herbivorous populations and structuring ecological communities naturally. Over 100 tachinid species have been employed in the biological control of several insects in different continents (STIREMAN et al., 2006).

We provide in this paper a check-list of the species of Tachinidae occurring in Brazil, in the state of Mato Grosso do Sul. All the four subfamilies of Tachinidae, Dexiinae,
Exoristinae, Phasiinae and Tachininae (O'Hara \& Wood, 2004), are represented in the Brazilian fauna and in the state.

\section{MATERIAL AND METHODS}

The Neotropical genera and species covered in our bibliographical review were mainly based on the catalogue of GUIMARÃes (1971) and the world genera check-list of O'HARA (2011). The searching databases used for the bibliographical review were the Zoological Records (http:// apps.webofknowledge.com), Web of Knowledge (http:// apps.webofknowledge.com), and Google Scholar (http:// scholar.google.com). To check the taxonomic validity of each name, we also consulted the Systema Dipterorum (http:// www.diptera.org/NomenclatorSearch.php). Subfamily and tribe arrangements were based mainly on HERTING \& DELYDraskovits (1993) and O'HARA \& WOOD (2004). In our search, we only considered data from published articles, without considering neither Master dissertations and $\mathrm{PhD}$ theses, nor specimens' labels from collections.

\section{RESULTS}

Check-list of the species of Mato Grosso do Sul State. We found 39 species and 24 genera of Tachinidae recorded to the state of Mato Grosso do Sul, belonging to the following subfamilies: Phasiinae ( 7 species), Dexiinae (3 
species), Tachininae (15 species) and Exoristinae (14 species).

PHASIINAE

CYLINDROMYIINI

Cylindromyia atra (Roeder, 1885)

Type-locality: "Puerto Rico". Distribution in Mato Grosso do Sul: Maracaju [Cerrado macroregion] and Três Lagoas

[Mata Atlântica macroregion] (GUIMARÃES, 1976).

\section{Cylindromyia brasiliana (Townsend, 1927)}

Type-locality: Brazil, São Paulo, Itaquecetuba. Distribution in Mato Grosso do Sul: Três Lagoas [Mata Atlântica macroregion] (GUIMARÃES, 1976).

\section{PARERIGONINI}

Neobrachelia grandis (Townsend, 1940)

Type-locality: Brazil, Mato Grosso [do Sul], Maracaju. Distribution in Mato Grosso do Sul: Maracaju [Cerrado macroregion] (TowNSEND, 1940).

\section{Neobrachelia mirabilis (Townsend, 1940)}

Type-locality: Brazil, Mato Grosso [do Sul], Maracaju. Distribution in Mato Grosso do Sul: Maracaju [Cerrado macroregion] (TowNSEND, 1940).

\section{PHASIINI}

Phasia chilensis (Macquart, 1851)

Type-locality: "Chile”. Distribution in Mato Grosso do Sul: Maracaju [Cerrado macroregion] (SUN \& MARSHALL, 2003).

\section{Phasia transita (Townsend, 1939)}

Type-locality: Brazil, Mato Grosso [do Sul], Maracaju. Distribution in Mato Grosso do Sul: Maracaju [Cerrado macroregion] (TowNSEND, 1939).

\section{TRICHOPODINI}

\section{Trichopoda giacomellii Blanchard, 1966}

Type-locality: Argentina, La Rioja. Distribution in Mato Grosso do Sul: [missing exact location] (CORRÊAFERREIRA et al., 2008).

\section{DEXIINAE \\ DEXIINI \\ Billaea argentaurea (Townsend, 1939)}

Type-locality: Mato Grosso [do Sul], Maracaju. Distribution in Mato Grosso do Sul: Maracaju [Cerrado macroregion] (GUIMARÃES, 1977).
Billaea claripalpis (Wulp, 1896)

Type-locality: Mexico, Guerrero, Chilpancingo. Distribution in Mato Grosso do Sul: Três Lagoas [Mata Atlântica macroregion], Maracaju and Bodoquena [Cerrado macroregion]; Miranda [Pantanal macroregion] (GuimarÃES, 1977).

\section{Billaea shannoni (Guimarães, 1977)}

Type-locality: Brazil, Mato Grosso, Maracaju (GUIMARÃes, 1977). Distribution in Mato Grosso do Sul: Maracaju [Cerrado macroregion] (GUIMARÃES, 1977).

\section{TACHININAE}

GERMARIINI

\section{Trochilochaeta transcendens Townsend, 1940}

Type-locality: Brazil, Mato Grosso [do Sul], Maracaju (Townsend, 1940). Distribution in Mato Grosso do Sul: Maracaju [Cerrado macroregion] (TownsEND, 1940).

\section{LESKIINI} Genea australis (Townsend, 1929)

Type-locality: Brazil, São Paulo, Itaquaquecetuba. Distribution in Mato Grosso do Sul: Três Lagoas [Mata Atlântica macroregion] (GUIMARÃES, 1975; NunEZ \& COURI, 2011).

Genea jaynesi (Aldrich, 1932)

Type-locality: Argentina, Tucuman. Distribution in Mato Grosso do Sul: Maracaju [Cerrado macroregion] (NuNEZ \& COURI, 2011)

ORMIINI

Ormia depleta (Wiedemann, 1830)

Type-locality: "Brazil". Distribution in Mato Grosso do Sul: Maracaju [Cerrado macroregion] (SABROSKY, 1953).

\section{POLIDEINI}

Chrysotachina braueri Townsend, 1931

Type-locality: "Brazil". Distribution in Mato Grosso do Sul: Maracaju [Cerrado macroregion] (NunEz et al., 2002).

\section{Chrysotachina panamensis Curran, 1939}

Type-locality: Panama, Canal Zone, Barro Colorado. Distribution in Mato Grosso do Sul: Maracaju [Cerrado macroregion] and Corumbá [Pantanal macroregion] (NunEz et al., 2002). 


\section{Chrysotachina tropicalis Nunez, Couri \& Guimarães, 2002}

Type-locality: Brazil, Mato Grosso do Sul, Maracaju. Distribution in Mato Grosso do Sul: Maracaju [Cerrado macroregion] (NuNEZ et al., 2002).

\section{TACHININI}

\section{Archytas arnaudi Guimarães, 1963}

Type-locality: Brazil, Mato Grosso [do Sul], Fazenda Murtinho [Porto Murtinho]. Distribution in Mato Grosso do Sul: Porto Murtinho [Chaco macroregion] (Guimarães, 1963b).

Archytas divisus (Walker, 1852)

Type-locality: Brazil, Pará. Distribution in Mato Grosso do Sul: Bodoquena [Cerrado macroregion] (GUIMARÃES, 1961).

Archytas lopesi Guimarães, 1961

Type-locality: Brazil, Mato Grosso [do Sul], Bodoquena. Distribution in Mato Grosso do Sul: Bodoquena [Cerrado macroregion] (GUIMARÃES, 1961).

\section{Archytas shannoni Guimarães, 1960}

Type-locality: Brazil, Mato Grosso [do Sul], Maracaju. Distribution in Mato Grosso do Sul: Maracaju [Cerrado macroregion] (GUIMARÃES, 1960).

\section{Archytas thompsoni Guimarães, 1973}

Type-locality: Brazil, Mato Grosso do Sul, Corumbá, Porto Esperança. Distribution in Mato Grosso do Sul: Corumbá and Porto Esperança [Pantanal macroregion] (GUIMARÃES, 1973).

\section{Adejeania andina Townsend, 1939}

Type-locality: Peru, Ollachea, Canyon of San Gabán River. Distribution in Mato Grosso do Sul: Maracaju [Cerrado macroregion] (GUIMARÃES, 1966).

\section{Copecrypta nitens (Wiedemann, 1830)}

Type-locality: Brazil, Mato Grosso, Chapada [dos Guimarães]. Distribution in Mato Grosso do Sul: Maracaju [Cerrado macroregion] (GUIMARÃES, 1963a).

\section{Neocuphocera nepos Townsend, 1927}

Type-locality: Brazil, São Paulo, (Itaquaquecetuba). Distribution in Mato Grosso do Sul: Bodoquena [Cerrado macroregion] (GUIMARÃES, 1963a).
EXORISTINAE

BLONDELIINI

Calodexia mattoensis (Townsend, 1939)

Type-locality: Brazil, Mato Grosso [do Sul], Maracaju. Distribution in Mato Grosso do Sul: Maracaju [Cerrado macroregion] (TowNSEND, 1939).

\section{Eucelatoria aurescens Townsend, 1917}

Type-locality: Brazil, Mato Grosso, Chapada (dos Guimarães) and [Mato Grosso do Sul] Corumbá. Distribution in Mato Grosso do Sul: Corumbá [Pantanal macroregion] (TownsEND, 1917).

Miamimyiops mattoensis Townsend, 1939

Type-locality: Brazil, Mato Grosso [do Sul], Maracaju (Townsend, 1939). Distribution in Mato Grosso do Sul: Maracaju [Cerrado macroregion] (TownSEND, 1939).

\section{Phyllophilopsis anomala (Townsend, 1939)}

Type-locality: Brazil, Mato Grosso [do Sul], Maracaju. Distribution in Mato Grosso do Sul: Maracaju [Cerrado macroregion] (TownSEND, 1939).

\section{Phyllophilopsis caudata (Townsend, 1927)}

Type-locality: Brazil, São Paulo, Itaquaquecetuba. Distribution in Mato Grosso do Sul: Maracaju [Cerrado macroregion] (TowNSEND, 1939).

\section{ERYCIINI}

\section{Lespesia brasiliensis (Townsend, 1917)}

Type-locality: Brazil, Mato Grosso [do Sul], Corumbá. Distribution in Mato Grosso do Sul: Corumbá [Pantanal macroregion] (TowNSEND, 1917).

\section{GONIINI \\ Atacta argentifrons Aldrich, 1925}

Type-locality: Brazil. Mato Grosso [do Sul], Corumbá. Distribution in Mato Grosso do Sul: Corumbá [Pantanal macroregion] (ALDRICH, 1925).

\section{Leschenaultia bigoti Toma \& Guimarães, 2002}

Type-locality: Peru, Huanuco, Tingo Maria. Distribution in Mato Grosso do Sul: Maracaju [Cerrado macroregion] (Toma \& Guimarães, 2002).

\section{Leschenaultia braueri Toma \& Guimarães, 2002}

Type-locality: Brazil, Mato Grosso, Chapada [dos Guimarães]. Distribution in Mato Grosso do Sul: Maracaju [Cerrado macroregion] (ToMA \& GUIMARÃES, 2002). 


\section{Leschenaultia leucophrys Robineau-Desvoidy, 1830}

Type-locality: "Surinam". [This is the senior synonym for L. leucophrys (Wiedemann, 1830)]. Distribution in Mato Grosso do Sul: Corumbá [Pantanal macroregion] and Maracaju [Cerrado macroregion] (TOMA \& GUIMARÃES, 2002).

\section{Thysanopsis albicauda Townsend, 1917}

Type-locality: Brazil, Mato Grosso, Chapada [dos Guimarães]. Distribution in Mato Grosso do Sul: Miranda [Pantanal macroregion] and Três Lagoas [Cerrado macroregion] (Tома, 2001).

\section{WINTHEMIINI Avibrissosturmia avida Townsend, 1927}

Type-locality: Peru, nr. Tabalosas. Distribution in Mato Grosso do Sul: Bodoquena [Cerrado macroregion] (Guimarães, 1983).

\section{Hemisturmia brasiliensis Guimarães, 1983}

Type-locality: Brazil, Mato Grosso do Sul, Três Lagoas. Distribution in Mato Grosso do Sul: Três Lagoas [Mata Atlântica macroregion] (GUIMARÃEs, 1983).

\section{Winthemia angusta Coelho, Carvalho \& Guimarães, 1989}

Type-locality: Brazil, Paraná, Foz do Iguaçu. Distribution in Mato Grosso do Sul: Três Lagoas [Mata Atlântica macroregion] (CoELHO et al.,1989).

Main research groups on Tachinidae in Brazil. The information below was mainly based on the Directory of South American Dipterists (http://zoo.bio.ufpr.br/diptera/ south/index.html).

Dr. Silvio Shigueo Nihei coordinates the Laboratory of Systematics and Biogeography of Diptera, Department of Zoology, Institute of Biosciences, Universidade de São Paulo, São Paulo. Main interests in Diptera: Tachinidae, Rhinophoridae, Calliphoridae, Oestridae, Muscidae, and Anthomyiidae.

Dr. Ronaldo Toma is currently professor at the University of Carabobo, Valencia, Venezuela, but he had successfully applied for a position at the Fundação Oswaldo Cruz, Campo Grande, and will soon assume that new position and come back to Brazil. Main interests in Diptera: Tachinidae and Calliphoridae.

Dr. Enio Nunez at the University Severino Sombra, Vassouras, Brazil. Main interest in Diptera: Tachinidae.

Dr. Claudio José Barros de Carvalho at the Department of Zoology, Universidade Federal do Paraná, Curitiba. Main interests in Diptera: Muscidae, Fanniidae, Anthomyiidae, Calliphoridae, and Tachinidae.
Main Tachinidae holdings in Brazil. The largest Tachinidae collection in Brazil is at the Museu de Zoologia da Universidade de São Paulo, São Paulo, São Paulo (MZSP), with 32,554 pinned adult specimens (CARVALHO et al., 2002). It has 847 type-specimens, representing 263 nominal species of Tachinidae (Toma \& NineI, 2006). Other important Tachinidae collections are housed at the Museu Nacional, Universidade Federal do Rio de Janeiro, Rio de Janeiro, Rio de Janeiro (MNRJ) with 9,397 specimens; Museu Paraense Emilio Goeldi, Belém, Pará (MPEG) with 4,990 specimens; Coleção de Entomologia Pe. Jesus Santiago Moure, Curitiba, Paraná (DZUP) with 4,871 specimens; and Instituto Nacional de Pesquisas Amazônicas, Manaus, Amazonas (INPA), with 3,849 specimens (CARVALHO et al., 2002).

Main knowledge gaps in the study of Brazilian Tachinidae. If anyone asks for one real example of taxonomic impediment we would say quickly and without thinking: "the Neotropical Tachinidae". There are many reasons supporting our statement. We do not have a number of experts publishing on Brazilian (and Neotropical) Tachinidae, we do not have identification keys to tribes or genera, we do not have up-to-date catalogues, and we do not have a sufficient number of research groups working on Brazilian (and Neotropical) Tachinidae. According to the Neotropical catalogue (GUIMARÃES, 1971), there are 2,864 species in 944 genera in the region. Most of these genera are monotypic, and the vast majority of them was described by Charles $\mathrm{H}$. T. Townsend. During a 61-year period (1884 to 1944) of intense and prolific activity, he was able to describe 1,491 genera and 1,555 species in Diptera (ARNAUd, 1958), most of them in the family Tachinidae, Townsend's favorite group, and most of them in the Neotropical region, his home in the last decades of his life. This all means that revising tribes or genera is the same as revising all the species of those groupings.

On the other hand, José Henrique Guimarães, between the 1960s and 1980, instead of describing more and more species and genera, spent his time mainly on revisionary works of Tachinidae grouping (tribes and large genera). He was not able to produce a generic key to the Neotropical Tachinidae, but his studies reflected a great contribution for the understanding of a number of tribes (e.g., Tachinini, Sophiini, Winthemiini, Cylindromyiini) and genera (e.g., Archytas, Adejeania, Peleteria, Lespesia, Billaea).

Eventually, some efforts have come from nonBrazilian authors: Charles H. Curran, John M. Aldrich, Reinhard, Curtis W. Sabrosky, and more recently, James O'HARA and D. Monty Wood. However, as they were or have been occupied with his own regional tachinid fauna, these foreign efforts added to the homemade ones, have not been enough to describe the Brazilian (and Neotropical) Tachinidae and to order its generic and suprageneric classification. The major concern here is that we should urgently train a number of young experts in Tachinidae in Brazil. It is NOT a matter of time to have a good and useful identification key and to have an up-to-date catalogue to Neotropical Tachinidae, it 
is indeed a matter of the number of local experts studying and publishing on Tachinidae.

Systematics of Tachinidae: a ten-year perspective. In the past 10 years, the number of postgraduate students in Brazil working on systematics of Tachinidae in their Master or PhD was only one, Enio Nunez finished his $\mathrm{PhD}$ in 2005 supervised by Marcia Couri, a muscoid expert at the Museu Nacional (Rio de Janeiro), and co-supervised by José Henrique Guimarães. Some years before, in 1999, Ronaldo Toma completed his $\mathrm{PhD}$ directly supervised by Guimarães and co-supervised by Claudio Carvalho at Universidade Federal do Paraná (Curitiba), and then he conducted his postdoc research with Guimarães in 1999 in São Paulo. Enio and Ronaldo were the last two researchers (among a total of three) who worked under the supervision of Guimarães on systematics of Tachinidae.

For the next 10 years, the perspectives are much better. In São Paulo, Silvio Nihei has been conducting active research on systematics of Tachinidae and is now supervising two PhDs and three Masters on the family. The planning is that in the next decade we have at least five or six young systematists working on the Neotropical Tachinidae. In fact, this is not much (with regard to the high diversity of Tachinidae in the region) but it is a better scenario than we have now. In Rio de Janeiro and Curitiba, Marcia Couri and Claudio Carvalho, respectively, have traditionally trained and formed young systematists in a number of families, mainly on Muscoidea, but also on Oestroidea, including Tachinidae. With the addition of these new young systematists, the efforts to elaborate reasonable and useful identification keys to the Neotropical genera and species will be multiplied, some of the more complicate tribes and genera could be finally studied and understood, and, therefore, the study of Neotropical groupings could finally, and actually, contribute to a better resolution in the classification of the world Tachinidae.

Acknowledgements. The authors thank the Fundação de Apoio ao Desenvolvimento do Ensino, Ciências e Tecnologia do Estado de Mato Grosso do Sul (Fundect) and Superintendência de Ciências e Tecnologia do Estado de Mato Grosso do Sul (Sucitec/MS) for the invitation to participate in this special issue of Iheringia, Série Zoologia and financial support for publication; research grants from CNPq (Proc. No. 563256/2010-9) and FAPESP (FAPESP) (Proc. No. 2010/52314-0), and the scholarships for ACL (CNPq Proc. No. 141033/2012-6), RVPD (CNPq Proc. No. 130204/2012-9) and FMG (CNPq Proc. No. 134257/2012-0).

\section{REFERENCES}

AlDRICH, J. M. 1925. New Diptera or two-winged flies in the United States National Museum. Proceedings of The United States National Museum Washington 66:1-36.

ARnaUd , P. H. JR. 1958. The entomological publication of Charles Henry Tyler Townsend (1863-1944); with lists of his new generic and specific names. Microentomology 23:1-63.

Carvalho, C. J. B. de; Couri, M. S.; Toma, R.; Rafael, J. A.; Harada, A. Y.; Bonatto, S. R.; Henriques, A. L. \& Gastal, H. A. O. 2002. Principais coleções brasileiras de Diptera: histórico e situação atual. In: Costa, C.; Vanin, S. A.; Lobo J. M. \& Melic, A. eds. Proyecto de Red Iberoamericana de Biogeografía y Entomología Sistemática PrIBES 2002. Zaragoza, SEA \& CYTED, p.37-52.
Carvalho, C. J. B. De; Rafael, J. A.; Couri, M. S. \& Silva, V. C. 2012. Diptera. In: Rafael, J. A.; Melo, G. A. R.; Carvalho, C. J. B. DE; CASARi S. A. \& Constantino, R. eds. Insetos do Brasil, Diversidade e Taxonomia. Ribeirão Preto, Holos, p.701-743.

Coelho, S. M. P.; Carvalho, C. J. B. de \& Guimarães, J. H. 1989. Chave e sinonímias para as espécies sul-americanas de Winthemia Robineau-Desvoidy (Diptera, Tachinidae). Revista Brasileira de Zoologia 6:271-296.

Corrêa-Ferreira, B. S.; Gómez, S. A.; Avila, C. J.; Oliveira, L. J. \& OliveirA, M. C. N. DE. 2008. Aspectos bioecológicos da interação de percevejos pentatomídeos no sistema de produção de soja. In: SARAIvA, O. F. \& Leite, R. M. V. B. DE C., eds. Resultados de pesquisa da Embrapa Soja 2005. Londrina, Embrapa Soja, p.85-90.

Guimarães, J. H. 1960. Contribuição ao conhecimento do gênero Archytas Jaennicke, 1867 (Diptera, Tachinidae). Memórias do Instituto Oswaldo Cruz 58:115-124.

GUIMARÃES, J. H. 1961. Terceira contribuição ao conhecimento do gênero Archytas Jaennicke, 1867 (Diptera, Tachinidae). Memórias do Instituto Oswaldo Cruz 59:355-395.

Guimarães, J. H. 1963a. Primeira contribuição ao conhecimento da tribu Cuphoceratini (Diptera, Tachinidae). Memórias do Instituto Oswaldo Cruz 61:41-72.

GuIMARÃes, J. H. 1963b. Quarta contribuição ao conhecimento do gênero Archytas Jaennicke, 1867 (Diptera, Tachinidae). Memórias do Instituto Oswaldo Cruz 61:153-164.

GuIMARÃES, J. H. 1966. Revisão parcial do gênero Adejeania Townsend, 1913 (Diptera, Tachinidae), com especial referência às espécies brasileiras. Arquivos de Zoologia 14:155-196.

Guimarães, J. H. 1971. 104. Family Tachinidae (Larvaevoridae). In: Papavero, N. ed. A catalog of the Diptera of the Americas South of the United States. São Paulo, Museu de Zoologia, Universidade de São Paulo, p.1-333.

GUIMARÃES, J. H. 1973. Two new neotropical Tachinidae Dejeaniini (Diptera, Cyclorrhapha). Revista Brasileira de Entomologia 17:121-125.

GuimARÃES, J. H. 1975. Three new records of Tachinidae (Diptera) attacking Diatraea ssp. (Lepidoptera, Pyralidae) in Brazil, with description on a new species. Revista Brasileira de Entomologia 19:127-132.

Guimarães, J. H. 1976. A revision of the genus Cylindromyia Meigen in the Americas south of the United States (Diptera, Tachinidae). Arquivos de Zoologia 27:1-50.

Guimarães, J. H. 1977. A revision of the genus Paratheresia Townsend (Diptera: Tachinidae, Theresiini). Papéis Avulsos de Zoologia 30:267288.

GuimarÃES, J. H. 1983. Contribution to the knowledge of the South American Winthemiini (Diptera, Tachinidae). Revista Brasileira de Entomologia 27:225-242.

Herting, B. \& Dely-Draskovits, A. 1993. Family Tachinidae. In: Soós, A. \& PAPP, L. eds. Catalogue of Palaearctic Diptera. AnthomyiidaeTachinidae. Hungarian, Natural History Museum. vol. 13, p.118-458.

O'HARA, J. E. 2011. World Genera of the Tachinidae (Diptera) and their Regional Occurence. p.1-71 Disponível em: $<$ http://www.nadsdiptera. org/Tach/Genera/Gentach_ver6.pdf $>$. Acessado em: 24.08.2012.

O'HarA, J. E. \& Wood, D. M. 2004. Catalogue of the Tachinidae (Diptera) of America north of Mexico. Memoirs on Entomology International 18:1-410.

Nunez, E. \& Couri, M. S. 2011. Revision of neotropical Genea Rondani (Diptera, Tachinidae, Tachininae, Leskiini). Papéis Avulsos de Zoologia 51:481-497.

Nunez, E.; Couri, M. S. \& Guimarães, J. H. 2002. Redescription of seven species of Chrysotachina Brauer \& Bergenstamm (Diptera, Tachinidae) of South America. Revista Brasileira de Zoologia 19:1-18.

SABrosky, C. W. 1953. Taxonomy and host relations of the tribe Ormiini in the Western Hemisphere (Diptera, Larvaevoridae). Proceedings of the Entomological Society of Washington 55:167-183.

Stireman, J. O.; O'Hara, J. E. \& Wood, D. M. 2006. Tachinidae: Evolution, Behavior, and Ecology. Annual of Review Entomology 51:525-530.

Sun, X. \& Marshall, S. A. 2003. Systematics of Phasia Latreille (Diptera: Tachinidae). Zootaxa 276:1-320.

Toma, R. 2001. Description of a new species of Thysanopsis (Diptera, Tachinidae). Iheringia, Série Zoologia 91:37-40. 
Toma, R. \& Guimarẽes, J. H. 2002. Taxonomic study of Leschenaultia Robineau-Desvoidy (Diptera, Tachinidae). Revista Brasileira de Entomologia 46:33-70.

Toma, R. \& Ninei, S. S. 2006. Catálogo do material-tipo de Tachinidae (Diptera) depositado no Museu de Zoologia da Universidade de São Paulo. Revista Brasileira de Entomologia 50:240-256.

Townsend, C. H. T. 1917. Second paper on Brazilian Muscoidea collected by Herbert H. Smith. Bulletin of the American Museum of Natural History 37:221-233.
Townsend, C. H. T. 1939. Seven new genera of Brazilian Oestromuscarian flies. Revista de Entomologia 10:446-452.

Townsend, C. H. T. 1940. New Oestroid flies from Brazil. Revista de Entomologia 11:889-894.

Wood, M. \& Zumbado, M. A. 2010. 113: Tachinidae. In: Brown, B.V.; Borkent, A.; Cumming, J. M.; Wood, D. M.; Woodley, N. E. \& Zumbado, M. A. eds. Manual of Central American Diptera. Ottawa, NRC Research Press. Vol. 2, p.1343-1417. 